\title{
Influence of domestic freezing on the biochemical composition and mineral contents of fish muscles
}

\author{
Mariam Mahmoud Sharaf
}

Department of Zoology, Faculty of Science, Suez Canal University, Ismailia, Egypt

\section{ABSTRACT}

The freezing of fish at $\left(-18^{\circ} \mathrm{C}\right)$ in the freezer compartment of a domestic refrigerator for 2, 4, 6 and 8 weeks influenced the biochemical composition and mineral contents of the muscles. The chemical analysis of the muscles of the studied fish recorded high values ( $\%$ dry weight) of protein, fat and ash contents and moisture for the fresh samples and there was a significant $(\mathrm{P}<0.05)$ decrease at the end of the eight weeks of freezing fish. The relationship between the four components of fresh and frozen Tilapia muscles was detected. There was only a significant $(\mathrm{P}<0.05)$ relationship between protein and fat contents (0.999) and between moisture and ash contents (0.998) after the 8 weeks of freezing, as for the mineral content of the frozen fish. The maximum values recorded throughout the freezing period were after 2 weeks of freezing $(\mathrm{Cu}, \mathrm{Ca}, \mathrm{K}$, and $\mathrm{Zn})$; after 4 weeks ( $\mathrm{P}$,Na and $\mathrm{K})$ and after 8 weeks $(\mathrm{Mg}, \mathrm{Fe}$ and $\mathrm{Na})$.

In conclusion, the present results determinate the quality changes during storage period ( 8 weeks) and how long fish muscle can be stored without any deterioration in a domestic refrigerator.

Keyword: fish, freezing, biochemical composition, mineral contents

\section{INTRODUCTION}

Fish is a major source of animal protein and minerals. Fish is widely consumed in many parts of the world because it has high protein content, low saturated fat and also contains omega fatty acids known to support good health. Marine foods are very rich sources of mineral components (Erkan and Özden, 2007). According to FAO (2008) and Gandotra et al. (2012) fish provides $20 \%$ of animal protein intake to about 2.6 billion people globally and at least $50 \%$ of animal protein intake for over 400 million in Asia and Africa. In developed countries, it provides only $13 \%$ of animal protein intake.

Preservation of fish can be achieved by various methods, i.e., refrigeration, freezing, salting, brining (wet salting), icing, smoking, glazing, drying, frying, etc. Refrigeration and freezing help in preserving fish by lowering temperature. At low temperature, micro-organisms become inactive, enzymatic activity also slows down, thus biochemical activities decreases. Consequently, the fish remain free from spoilage for longer duration (Gandotra et al., 2012).

The freezing of fish is an effective way of long term preservation and it has been shown that fish stored for up to three months under ideal conditions cannot be distinguished from fresh fish regarding colour, taste and texture (Cappeln et al., 1999; Nielsen and Jessen, 2007; Gandotra et al., 2012). The quality of frozen fish is controlled by many factors. Consideration must be given to the type of protective packaging used, maintenance of proper storage temperature and freezing properties of different species (Beroumand and Jooyandeh, 2010). 
The two means of spoilage during frozen storage that can change a good-tasting fish into a poor-tasting one are oxidation and dehydration. Dehydration is the drying out of frozen foods after freezing. The advanced stage of dehydration is known as "freezer burn." It causes a chalky-white appearance on the skin of fish and a browning of the flesh. It also causes fish to become tough, dry and to lose flavour. Dehydration can be prevented by using a packaging material which provides a good vapour barrier.

Oxidation, A large percentage of the fats and oils found in fish are polyunsaturated which make fish very healthful to eat. But, at the same time, these polyunsaturated oils are susceptible to oxidation. When oxygen comes in contact with fish during frozen storage, the fats and oils turn rancid, resulting in unpleasant flavours. You can retard the onset of rancidity by choosing a packaging material that forms a barrier to oxygen and by forcing out all air from the package before freezing Foucat et al. (2001) and Beroumand and Jooyandeh (2010). Refrigeration and the addition of antioxidants to the fish diet minimize the undesirable effects of lipid peroxidations (Scaife et al., 2000; Pirini et al., 2000).

The aim of the present study is to find out the changes in biochemical composition and mineral contents of raw muscle of Tilapia fish stored in frozen conditions $\left(-18^{\circ} \mathrm{C}\right)$. Thus determining the quality change during storage period $(8$ weeks) and how long fish muscle can be stored without any deterioration in domestic refrigerator.

\section{MATERIAL AND METHODS}

\section{Fish samples}

A total of 30 fresh Tilapia nilotica fish were obtained from commercial catches. They were immediately washed and drained. Fish were packed separatly in a polyethylene bag and were equally divided into five groups. Fish were frozen by freezer compartment of domestic refrigerator at a temperature $-18^{\circ} \mathrm{C}$ for different times $(0,2,4,6$ and 8 weeks). At the time designated, frozen fish were thawed using running water $\left(25-26^{\circ} \mathrm{C}\right)$. The flesh was then excised from those fish for analysis. The four frozen and fresh groups were analyzed for the biochemical composition of the dried tissues.

\section{Biochemical analysis}

Moisture content was determined by oven drying the muscle samples at $105^{\circ} \mathrm{C}$ until constant weight (about 12hr). The protein content was determined using the micro-Kjedal method, fat (Soxhlet ether extractives) and ash (residual after heating at $550^{\circ} \mathrm{C}$ for $12 \mathrm{hr}$ ) were determined using standard methods reported by AOAC (1995).

Mineral contents concentrations $\mathrm{Cu}, \mathrm{Fe}, \mathrm{Ca}, \mathrm{Mg}, \mathrm{K}, \mathrm{Na}, \mathrm{Zn}$ and $\mathrm{P}$ were measured in the fish muscles according to the method reported by American Public Health Association, APHA (1989) using flame atomic absorption spectrophotometer (Perkin Elmer 2280).

\section{Statistical analysis}

The obtained data were statistically analyzed using one-way analysis of variance (ANOVA) procedure. Analysis system was done using SPSS program version SPSS Statistics ver. 18.0 (SPSS, Richmond, USA) as described by Dytham (1999). Means were compared using Duncan's test (1955). All data were expressed as means Standard Error. The significance level was set at the probability level of $\mathrm{P}<0.05$. 


\section{RESULTS AND DISCUSSION}

The proximate composition of Tilapia that was frozen in a freezer $\left(-18^{\circ} \mathrm{C}\right)$ compartment of the refrigerator for different number of days prior analysis is presented in Table (1).

Table 1: biochemical composition (\%) fresh and frozen Tilapia muscles.

\begin{tabular}{|c|c|c|c|c|c|}
\hline \multirow{2}{*}{$\begin{array}{c}\text { Proximal } \\
\text { composition }\end{array}$} & zero & 2 & 4 & 6 & 8 \\
\cline { 2 - 6 } & $77.38^{\mathrm{a}} \pm 0.44$ & $76.32^{\mathrm{ab}} \pm 0.33$ & $76.24^{\mathrm{ab}} \pm 0.33$ & $76.31^{\mathrm{ab}} \pm 0.34$ & $75.68^{\mathrm{b}} \pm 0.58$ \\
\hline Protein & $18.53 \pm 0.62$ & $18.15 \pm 0.35$ & $17.81 \pm 0.14$ & $17.69 \pm 0.26$ & $17.60 \pm 0.75$ \\
\hline Fat & $5.77 \pm 0.03$ & $5.46 \pm 0.05$ & $5.62 \pm 0.28$ & $5.57 \pm 0.24$ & $5.35 \pm 0.25$ \\
\hline Ash & $76.2^{\mathrm{a}} \pm 0.27$ & $75.16^{\mathrm{b}} \pm 0.13$ & $75.27^{\mathrm{b}} \pm 0.28$ & $75.12^{\mathrm{b}} \pm 0.31$ & $75.01^{\mathrm{b}} \pm 0.28$ \\
\hline Moisture
\end{tabular}

Means followed by the same superscript in the same row are not significantly different according to Duncan's multiple range test $(\mathrm{P}<0.05)$.

The highest protein content $\left(77.38^{\mathrm{a}} \pm 0.44\right)$ was recorded for fresh samples that value significantly $(\mathrm{P}<0.05)$ decreased to $\left(75.68^{\mathrm{b}} \pm 0.58\right)$ after 8 weeks of freezing, the same as Arannilewa et al. (2005) findings on frozen slices of fish Tilapia Sarotherodun galiaenus; Siddique et al. (2011) on Puntius sp. reported significant decrease in protein content during frozen storage and Gandotra et al., (2012) on frozen fish muscle of Labeo rohita in Puntius sp. for 21 days.

They stated that the decrease in protein could be connected with denaturation of fish protein that is associated with frozen fish. Reay (1993) and Mills (1975) had the same explanation.

The highest fat content $(18.53 \pm 0.62)$ was observed in the fresh samples and the least $(17.60 \pm 0.75)$ was recorded for fish samples that was frozen for 8 weeks. The present findings were reported by Arannilewa et al. (2005) in Tilapia; Siddique et al. (2011) and Gandotra et al. (2012). McGill et al. (1974) and Josephson and Lindsay (1987) also observed a significant loss in total lipid content when stored at low temperature. Those workers attributed this loss due to oxidation of lipid that is the major cause of deterioration of fish.

In addition, the results shown in Table (1) revealed that the ash content decreased significantly $(\mathrm{P}<0.05)$ from $5.77 \pm 0.03$ in the fresh samples to $5.35 \pm 0.25$ at the end of the eight weeks of freezing. These results are in agreement with Gandotra et al. (2012). While Arannilewa et al. (2005) observed that the ash content remained almost the same throughout the 60 days of frozen storage of Tilapia slices. The decrease in ash content was attributed to the drip loss during thawing process.

In the present study, moisture content was found to be $76.2^{\mathrm{a}} \pm 0.27$ in the fresh samples and it decreased significantly $(\mathrm{P}<0.05)$ to the value of $75.01^{\mathrm{b}} \pm 0.28$ after the eight weeks of freezing at $-18^{\circ} \mathrm{C}$. These results are in accordance with Alasalvar et al. (2002) who reported a decrease in total moisture content in sea bass (Dicentrarchus labrax) fillets during frozen storage. This decrease in moisture content was attributed to the sublimation of ice in frozen storage and drip loss during thawing process, Beniakul et al. (2005) and Gandotra et al. (2012). On contrary to the results of present study, Siddique et al. (2011) in Puntius sp. found an increasing trend in moisture content. Zamir et al. (1998) attributed this increase to the loss of water holding capacity of tissue, while Arannilewa et al. (2005) observed that moisture content remained almost the same throughout the 60 days of frozen storage of Tilapia slices. 
The relationships among the four components of fresh and frozen Tilapia muscles (Table 2) were detected by SPSS program version to get the correlation coefficient (r). The relationship was considered strong when the value of (r) was close to unity. There was only a significant relationship between protein and fat contents (0.999) and between moisture and ash contents (0.998) after the 8 weeks freezing.

Table 2: The relationship between the four components of fresh and frozen Tilapia muscles.

\begin{tabular}{|c|c|c|c|c|c|}
\hline Variables & $\begin{array}{c}\text { Zero week } \\
(\mathrm{r})\end{array}$ & $\begin{array}{c}2 \text { weeks } \\
(\mathrm{r})\end{array}$ & $\begin{array}{c}4 \text { weeks } \\
(\mathrm{r})\end{array}$ & $\begin{array}{c}6 \text { weeks } \\
(\mathrm{r})\end{array}$ & $\begin{array}{c}8 \text { weeks } \\
(\mathrm{r})\end{array}$ \\
\hline Protein/ Fat & -0.933 & 0.945 & -0.726 & -0.921 & $-0.999^{*}$ \\
Protein/ ash & -0.313 & -0.665 & 0.174 & 0.773 & 0.853 \\
Protein/ moisture & 0.721 & -0.996 & 0.817 & 0.465 & 0.817 \\
Moisture/ Fat & 0.420 & -0.970 & -0.197 & -0.082 & -0.849 \\
Moisture/ ash & -0.884 & 0.727 & -0.426 & -0.921 & $0.998^{*}$ \\
Fat/ ash & -0.053 & -0.873 & -0.804 & 0.464 & -0.882 \\
\hline
\end{tabular}

$\mathrm{P}<0.05$ significant $(*)$

$\mathrm{r}=$ correlation coefficient

As for the mineral content of the frozen fish (Fig. 1). The maximum values recorded throughout the freezing period were after 2 weeks of freezing $(\mathrm{Cu}, \mathrm{Ca}, \mathrm{K}$, and $\mathrm{Zn}$ ); after 4 weeks (P,Na and $\mathrm{K}$ ) and after 8 weeks (Mg,Fe and $\mathrm{Na}$ ). This may mean that there was not a clear relationship between the mineral content concentration and the different freezing period. Sikorski and Sunpan (1992) and Arannilewa et al. (2005) observed a slight change with respect to freezing period in all the minerals evaluated and attributed that to the drip loss and the dehydration associated with frozen storage.

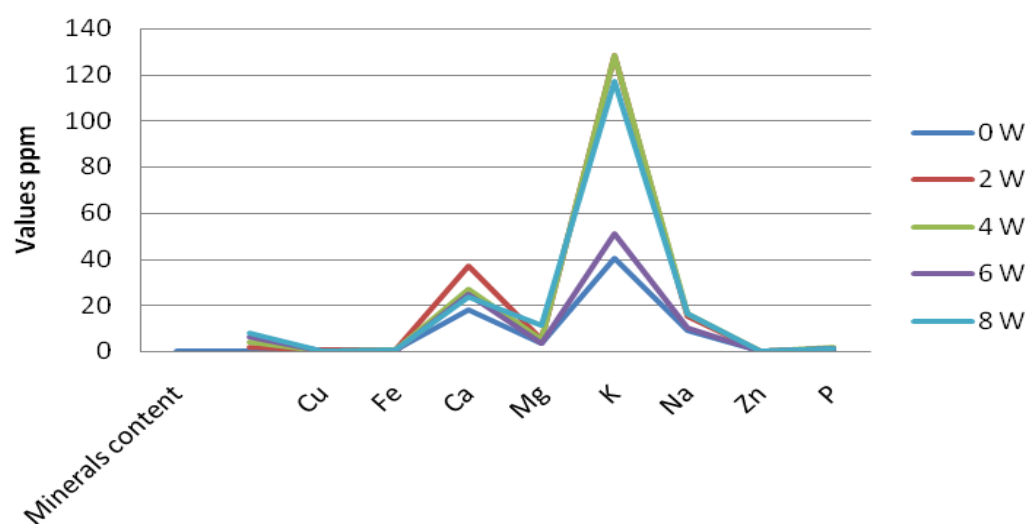

Fig. 1: The mineral content concentration (ppm) in fresh and frozen fish muscles.

However, the main functions of essential minerals include skeletal structure, maintenance of colloidal system and regulation of acid-base equilibrium. Minerals also constitute important components of hormones, enzymes and enzyme activators (Belitz and Grosch, 2001). Ca and P are necessary to maintain an optimal bone development, with more of both minerals being required during childhood and growing stages to prevent rickets and osteomalacia (Erkan and Özden, 2007). It is known that a variation in the mineral composition of marine foods is closely related to seasonal and biological differences (species, size, dark/white muscle, age, sex and sexual maturity), area of catch, processing method, food source and environmental conditions (water chemistry, salinity, temperature and contamination) (Alasalvar et al., 2002; Turhan et al., 2004). 
Furthermore, fish species are known to provide high contents of important constituents for the human diet such as nutritional and readily-digestive proteins, lipid-soluble vitamins, microelements and polyunsaturated fatty acids. However, marine and fresh water products are known to easily deteriorate during postmortem storage and processing. Therefore, freezing and frozen storage are important methods for the preservation of fish species. Although many damage pathways are inhibited by such processes, undesirable reactions associated with lipids and proteins have shown to occur, leading to detrimental changes in nutritional and sensory properties (Beroumand and Jooyandeh, 2010).

Finally, freezing is a common practice in the meat, fish and other animal protein based industry, because it preserved the quality for an extended time and offers several advantages such as insignificant alterations in the product dimensions and minimum deterioration in products colour, flavour and texture. However, there are some disadvantages associated with frozen storage including freezer burn, product dehydration, rancidity, drip loss and product bleaching which can have an overall effect on the quality of the frozen foods (Beroumand and Jooyandeh, 2010).

In conclusion, fish is a good source of protein, fat and minerals and that quality of fish decrease during frozen storage. So, the most benefit is from eating fresh fish.

\section{REFERENCES}

Alasalvar, C., Taylor, K.D.A., Zubcov, E., Shahidi, F., Alexis, M. (2002). Differentiation of cultured and wild sea bass (Dicentrarchus labrax): Total lipid content, fatty acid and trace mineral composition. Food Chem., 79: 145150.

AOAC (1995). Official methods of analysis, $16^{\text {th }}$ (eds.). Association of Official Analytical Chemists, Washington, D.C., USA.

APHA (American Public Health Association) (1989). Standard Methods for the Examination of Water. 17th (eds.) Greenberg, A. D. (eds.) Washington, D.C., USA.

Arannilewa, S. T.; Salawu, S. O.; Sorungbe, A. A. and Olasa lawu, B. B. (2005). Effect of frozen period on the chemical, microbiological and sensory quality of frozen tilapia fish (Sarotherod on galilaleus). Afr. J. Biotech., 4(8): 852-855.

Belitz, H.D. and Grosch, W. (2001). Schieberle, P. Lehrbuch der Lebensmittelchemie, ISBN 3-540-41096-1 5. Aufl. Springer Verlag, Berlin, Heidelberg, New York.

Beniakul, S., Visessanguan W., Thongkaew, C. and Tanaka, M. (2005). Effect of frozen storage on chemical and gel-forming properties of fish commonly used for surimi production in Thailand. Food Hydrogolloids, 19: 197-207.

Beroumand, A. A. and Jooyandeh, H. (2010). Storage Quality and Chemical and Structural Changes of Fresh and Frozen-Thawed Fish. World Journal of Fish and Marine Sciences, 2(3): 251-253.

Cappeln, G., Nielsen, J., and Jessen, F. (1999). Synthesis and degradation of adenosine triphosphate in cod (Gadus morhua) at subzero temperatures. Journal of the Science of Food and Agriculture, 79(8): 1099-1104.

Duncan, D. B. (1955). Multiple range and multiple F-test. Biometrics, 11: 1-42.

Dytham, C. (1999). Choosing and using statistics: A Biologist's Guide. Blackwell Science Ltd., London, UK. Pp.147. 
Erkan, E. and Özden, Ö(2007). Proximate composition and mineral contents in aqua cultured sea bass (Dicentrarchus labrax), sea bream (Sparus aurata) analyzed by ICP-MS. Food Chemistry, 102: 721-725.

FAO (2008). Fisheries and Aquaculture Report. No. 889. Cairo, FAO, 61pp.

Foucat, L., R. Taylor, R. Labas and J. Renou, (2001). Characterization of frozen fish by NMR imaging and histology. American Laboratory, 33(16): 38-43.

Gandotra, R., Koul, M., Gupta, S. and Sharma, S. (2012). Change In Proximate Composition And Microbial Count By Low Temperature preservation In Fish Muscle Of Labeo Rohita (Ham- Buch). IOSR Journal of Pharmacy and Biological Sciences (IOSRJPBS), 2(1): 13-17.

Josephson, D. B. and Lindsay, R. C. (1987). Retroidol degradation of unsaturated aldehydes. J.A.O.C.S. 64(7): 204-209.

Mac Gill, A.S.; Hard, R.; Burt J. R. (1974). Hept-cis-4-enal and its contribution to the off flavor in cold stored cod. J. Sci. Food and Agricult., 25: 1477-1489.

Mills, A. (1975): Measuring changes that occur during frozen storage of fish. J. Food. Tech., 10: 483-496.

Nielsen, J. and Jessen, F. (2007). Quality of Frozen Fish. In: Handbook of Meat, Poultry and Seafood Quality. Nollet, L. M. L. (Ed.) Blackwell Publishing, Iowa: 577-586.

Pirini, M.; Gatta, P.P.; Testi, S.; Trigari, G. and Monetti, P. G. (2000). Effect of refrigerated storage on muscle lipid quality of sea bass (Dicentrarchus labrax) fed on diets containing different levels of vitamin E. Food Chem., 68: 289-293.

Reay, G.A. (1933). The influence of freezing temperature on haddock's muscle. JSOC Chem Ind. London. 52: 256.

Scaife, J.R., Onibi, G.E., Murray, I., Fletcher T.C. and Houlihan, D.F. (2000). Influence of -tocopherol acetate on the short- and long-term storage properties of fillets from Atlantic salmon Salmo salar fed a high lipid diet. Aquacult. Nutr., 6: 65-71.

Siddique, M.N., Hasan, M.J., Reza, M.Z., Islam, M.R., Boduruzaman, M., Forhadur, M. and Reza, S. (2011). Effect of freezing time on nutritional value of Jatpunti (Puntius sophore), Sarpunti (P. sarana) and Thaisarpunti ( $P$. gonionotus). Bangladesh Research Publications Journal, 5(4): 387-392.

Sikorski, Z.F. and Sunpan, B. (1992). Preservation of seafood quality. In: Shahidi, F., Botter, J.R. (Eds.). Seafood's Chemistry Processing.

Turhan, S., Üstün, S. N., and Altunkaynak, B. (2004). Eect of cooking methods on total and heme iron contents of anchovy (Engraulis encrasicholus). Food Chemistry, 88(2): 169-172.

Zamir, M., Qasim, R., and Ullah, A. (1998). Changes in physical and chemical constituents of crab meat during storage at refrigerator temperature $\left(7 \pm 2^{\circ} \mathrm{C}\right)$. Pak. J. of Pharma. Sci. 11(1): 27-33. 